\title{
Material Development in Production Ecrite Intermediaire by Sipda to Improve the Writing Ability the Student of French Departement at Faculty of Languages and Arts at One of State Universities in Northen Island of Indonesia
}

\author{
Tengku Ratna Soraya ${ }^{1}$, Zulherman ${ }^{2}$, Nurilam Harianja ${ }^{3}$, Hesti Fibriasari ${ }^{4}$ \\ 1,23,4 Department of French Education, Faculty of Languages and Arts, Universitas Negeri Medan, \\ Indonesia \\ Email: ratnasoraya@unimed.ac.id, zulhermanghani@gmail.com,nurilam_harianja@gmail.com, \\ hesti@unimed.ac.id
}

\begin{abstract}
This study aims to develop teaching materials in Production Ecrite Intermediare course to improve the writing ability the student of french departement at Faculty of Languages and Arts at One of State Universities in Northen Island of Indonesia by using SIPDA. This research was conducted to response the condition of covid pandemic situation that uses distance learning courses where students learn from their own homes. This research followed the $R \mathcal{E} D$ model proposed by Borg $\mathcal{E}$ Gall with the procedure analysing the student's need, collecting the ressource of development, design the material, evaluatingexisting the materials based on the validation of experts judgement, field testing, revising, and finishing the final product. This research was carried out in the French Language Education Study Program FBS UNIMED by developing SIPDA-based teaching materials in lectures, to find out that these teaching materials can improve the writing skills of students of French Language Education Study Program at FBS Unimed. The results of this study show that SIPDA is very effective in helping students to improve the writing ability of French texts. This research recommends to the lecturers of French courses in general to using SIPDA in the teaching and learning process of writing in the classroom of Production Ecrite Intermediaire.
\end{abstract}

Keywords: material development; production ecrite intermediaire; SIPDA

\section{Introduction}

The emergence of a pandemic caused by the Corona virus in Indonesia has resulted in a change in the pattern of activities of Indonesian people, including in the world of education. The government tries its best to prevent the spread of this virus, one of which is through a circular letter from the Ministry of Education and Culture (Kemendikbud) of the Directorate of Higher Education No.1 of 2020 concerning the prevention of the spread of Corona Virus Disease (Covid-19) in universities. Through this circular, the Ministry of Education and Culture gave instructions to universities to organize distance learning and advised students to study from their homes.

This form of distance learning is an alternative form of learning that can be implemented during the Covid-19 emergency period. According to Moore, Dickson-Deane, \& Galyen (2011), online learning is learning that uses the internet network with accessibility, connectivity, flexibility, and the ability to generate various types of learning interactions. Research conducted by Zhang et al., (2008) shows that the use of the internet and multimedia technology is able to change the way of conveying knowledge and can be an alternative to learning carried out in traditional ways. 
As one of the higher education institutions in Indonesia, State University of Medan since the end of March 2020 has implemented learning through E-learning. This resulted in lecturers being required to design teaching materials online by utilizing the E-learning network that was already available on campus. Learning through E-learning in principle, it is a learning process based on electronics. In this case, it refers to the use of various electronic devices (especially computers) as learning media. Learning is the process of changing behavior due to interactions among individuals and the environment. Changes in behavior include changes in knowledge, understanding, attitudes, skills, motivation, interests, thinking abilities and so on (Resien, 2020).

The development of technology, communication and information, especially the internet has become a demand for teachers in Indonesia to be able to use it as a source of positive learning media in supporting teaching and learning processes (Prasasti, 2019). According to Syakur (2020) the use of technology in learning problems in the classroom is expected to be able to provide solutions in overcoming learning in the classroom. This is caused by the less optimal role of a lecturer in utilizing technology in the world of education (Shah et al., 2011, Sulam et al., 2019). The advancement of technology, communication, and information, particularly the internet, has provided a platform for teachers in Indonesia to be able to utilize it as a source of positive educational media to assist in the teaching and learning processes. The existence of e-learning has a big influence on the learning process. Even many universities that have used e-learning as a tool so that the teaching and learning process can still be carried out without the need of facing each other from both parties (Syakur, 2020).

French Department of learning has four competencies, Production Ecrite (writing), Production Orale (speaking), Compréhension Ecrite (reading), and Compréhension Orale (listening). Writing skill as one of the important skills that students get mastered, because they must be able to convey ideas, thoughts, opinions in writing and master grammar in order to be able to write French sentences correctly. Writing is a linguistic skill that must be learned continuously. Good writing is writing that provides clear information to the reader. In learning French, writing courses are given in stages each semester because writing is a benchmark for someone to express their opinion in writing, besides writing is an important point in the selection to apply for jobs in French companies. Therefore, writing learning materials must be tailored to the needs of students in the world of work later.

According to the National Center for Competency Based Training (2008), teaching materials are as forms of materials used to assist teachers or instructors in carrying out the learning process. The material referred to can be written or unwritten forms. The point of views of other experts says that teaching materials are a set of materials arranged systematically, both written and unwritten, so that create an environment or atmosphere in which students learn.

SIPDA or the Medan State University Online Learning System is an online learning application that can be accessed via a website (http://sipda.unimed.ac.id). SIPDA was developed based on moodle and is an update of SIPOEL (Electronic Learning Portal System) which was previously used by Medan State University in online learning. The SIPDA elearning system has been adjusted to the latest technological developments so that it can simplify the learning process. SIPDA uses an LMS (Learning Management System) based on an open source CMS. The main page of SIPDA is presented as follows: 


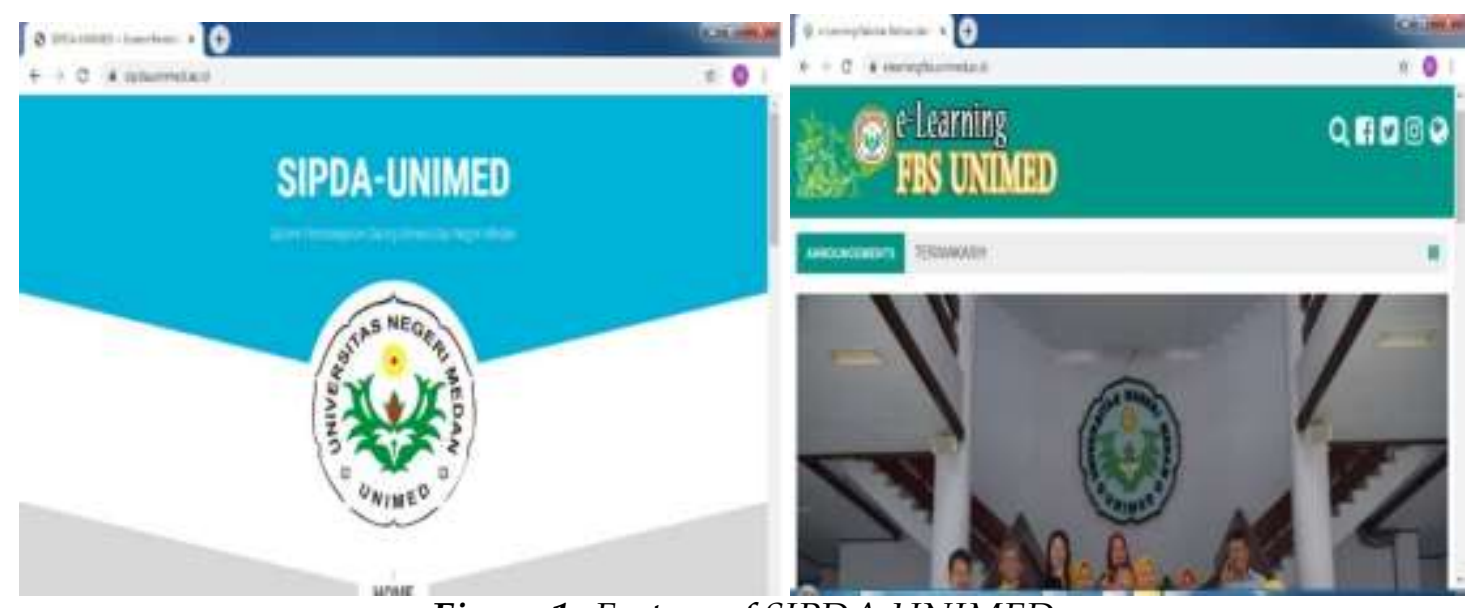

Figure 1. Feature of SIPDA UNIMED

The use of E-learning aims to accelerate the learning process. Learning is partially transferred to blended learning (combining e-learning and face-to-face). The application has been effectively used starting from the even semester 2018-2019. The problem that has been found so far in the French Language Education Study Program is the inadequate use of elearning. So that it takes more maximum effort in its use in the learning process.

To solve the problem in this study, learning material Production Ecrite Intermediaire course is developed based on SIPDA which aims that it can be improving the writing ability of the students.

\section{Research Methods}

This study uses an R\&D (Research and Development) approach. R \& D research is a basic research activity to obtain information on user needs (needs assessment), followed by development activities to produce products and test the effectiveness of these products. This research uses an $\mathrm{R} \& \mathrm{D}$ approach because this research will produce a product in the form of SIPDA-based teaching materials in the Production Écrite Intermédiaire course. Borg and Gall revealed that there are 10 steps in the development research process (2003), but in the Puslitjaknov Team (2008), the development research procedure according to Borg and Gall can be done more simply involving 5 main steps, namely: (1) Conducting product analysis to be developed ; (2) Develop the initial product; (3) Expert validation and revision; (4) Smallscale field trials and product revisions; (5) Large-scale field trials and final products. The steps can be described as follows:

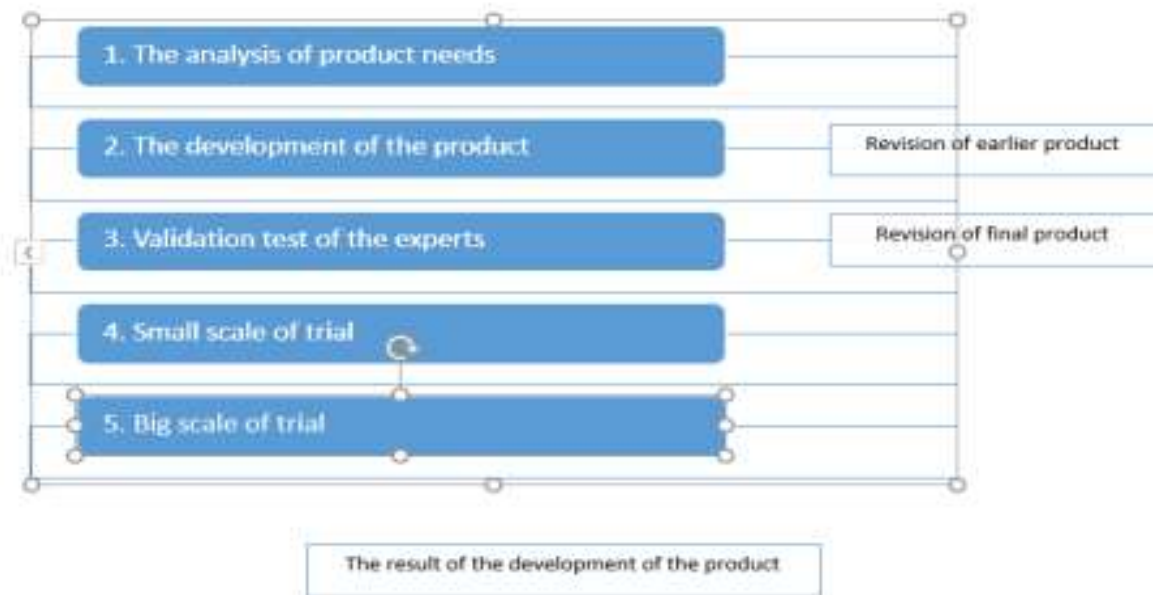

Figure 2. Borg and Gall's Steps (2003) 
This research was carried out in the State University of Medan majoring French Education Study Program with the research subjects consisting of 1 media expert, 1 material expert, and 10 students in small-scale field trials. The data collection techniques used in this study was observation, interviews, and questionnaires. Observations were made when research was going to be carried out to obtain data as a basis for conducting research and development. Interviews were conducted with writing lecturers and students to obtain data about the needs in research and development. Questionnaires are used to obtain data on the quality assessment of teaching materials developed according to material experts, as well as questionnaires to obtain quality assessment data from material experts, as well as students in small-scale field trials.Furthermore, the experts gave a score for each indicator in each aspect of the assessment consisting of 5 (five) rating scales. To obtain effectiveness data, the researcher provided the observer with process observation sheets and student observation sheets during the learning process. Then, they assessed each observation indicator.From each aspect of the assessment category, there are 5 (five) rating scales. Likewise with the student response questionnaire and learning, the questionnaire consists of 5 (five) assessment scales.

\section{Discussion}

This research is a research and development with aim to develop a learning material of Production Écrite Intermédiaire, so the product of this research is learning material Production Écrite Intermédiaire based on SIPDA. The objectives of this research are: (1) to describe the process of material development in Production Écrite Intermédiaire course based on SIPDA, (2) to describe the implementation of material learning Production Écrite Intermédiaire based on SIPDA to improve the student's writing ability.

\subsection{Results of Process the Material Development in Production Écrite Intermédiaire Course Based on SIPDA}

The research and development steps in this research include needs analysis, data collection, product design, validation, and design revision. The following describes the five steps.

\subsection{Problem Analysis}

Based on a preliminary study in the French Language Education Study Program and literature study in the guidebooks used in the French Language Study Program as well as observation and distribution of questionnaires in order to find out the potential and problems that exist in the Production Écrite Intermédiaire course, the potentials and the problems faced are formulated. in teaching writing skills for third semester students. Observations were made when learning French at the Unimed French Language Education Study Program. The following is the observation sheet used:

Table 1. Observation Sheet

\begin{tabular}{|l|l|c|c|}
\hline No. & Aspects Observed & \multicolumn{2}{|c|}{ Implementation } \\
\cline { 3 - 4 } & & There is & Not \\
\hline 1 & Production Écrite Intermédiaire lessons in class & $\sqrt{ }$ & \\
\hline 2 & $\begin{array}{l}\text { Learning support facilities } \\
\text { a. Computer / Laptop } \\
\text { b. Speaker }\end{array}$ & $\sqrt{ }$ & \\
\hline
\end{tabular}




\begin{tabular}{|l|l|c|c|}
\hline & c. LCD Projector & $\sqrt{ }$ & \\
\hline 3 & Learning media used & $\sqrt{ }$ & \\
& a. Book & $\sqrt{ }$ & \\
& b. Cassette & $\sqrt{ }$ & \\
& c. Native speakers & & \\
& d. Interactive CD & & \\
& e. Web e-Learning & & \\
& f. Tutorial video & & \\
& g. Power point & $\sqrt{ }$ & \\
\hline
\end{tabular}

\subsection{Data Collection}

In this step, a preliminary study with the documentation method is carried out to find out what material is in the Production Écrite Intermédiaire course for semester III students. The data obtained includes themes contained in the Production Écrite Intermédiaire material, namely Continuer en Français, Recevoir des Amis, Faire des Etudes, Travailler, et S'informer sur l'Actualité. For the needs analysis, questionnaires and interviews were used. The needs analysis questionnaire was distributed to students and lecturers in the French Language Education Study Program, while short interviews were conducted with French teachers in the Production Écrite Intermédiaire course.

The questionnaire distributed was a questionnaire for student needs. The researcher explains about the questionnaire and the procedure for filling out the questionnaire, then students can fill out the questionnaire that has been divided.

\subsection{Research and Development Instruments}

The research instrument is a tool used to collect data. This study uses non-test instruments. The non-test instruments used in this study were in the form of interviews with lecturers' needs and questionnaires for student needs for SIPDA-based Production Écrite Intermédiaire teaching materials for third semester students. The data needed, namely the data on the needs of SIPDA-based Production Écrite Intermédiaire teaching materials for third semester students.

To obtain data needs, two methods are used. The first method is a needs questionnaire addressed to French Language Education Study Program students. This questionnaire is used to obtain data needs. The questionnaire contains things that students want and need in writing skills. The second method is interviews aimed at lecturers. To get an overview of the instruments used in this study, please see the table below:

Table 2. Needs Analysis

\begin{tabular}{|c|c|c|c|}
\hline No & Data & Subject & Instrument \\
\hline 1 & The need for SIPDA-based & Lecturers who teach and & \\
& $\begin{array}{c}\text { Production Écrite } \\
\text { Intermédiaire teaching } \\
\text { materials to improve the } \\
\text { writing skills of students of } \\
\text { the French Language }\end{array}$ & $\begin{array}{c}\text { Production Écrite } \\
\text { Intermédiaire course in } \\
\text { French Education Study }\end{array}$ & $\begin{array}{c}\text { Needs interview } \\
\text { lecturers and } \\
\text { questionnaires } \\
\text { student needs }\end{array}$ \\
& Education Study Program & Program & \\
\hline
\end{tabular}


Questionnaire Student needs for the SIPDA-based Production Écrite Intermediate teaching materials for third semester students. Questionnaires are used to obtain data as a reference for media development. In this questionnaire, the matters discussed include (1) the writing learning process that has been carried out, (2) obstacles to writing skills, and (3) expected writing learning media.

Interview about the lecturers' needs for SIPDA-based Production Écrite Intermedia teaching materials for third semester students. Matters discussed in the interview for the lecturers' needs include (1) the writing learning process that has been carried out so far, and (2) the offer of teaching materials to be developed.

\subsection{Product Design}

In this step, it starts with designing materials that are in accordance with the RPS and will be included in the SIPDA. At this stage the text is made in a clear main display, as well as an animation that is able to clarify the content of the material being displayed, teaching materials that make it easier for students to learn to write simple text.

\subsection{Validation}

In the validation stage, a French linguist is selected who is considered capable of knowing the suitability of the product design that has been made. This will be done to find out the weaknesses and weaknesses. According to Sugiyono (2010:414) design validation is an activity process to assess whether the product design, in this case the new work system will rationally be more effective than the old one or not. The opinion above provides the understanding that educational products developed before being implemented must go through an assessment process. In addition, product validation can be done by bringing in several experienced experts to assess the newly designed product. In validating a product according to Sugiyono (2010: 414) every expert is asked to assess the design, so that further weaknesses and strengths can be found.

In testing the tool, a validation sheet is created which will be used to test the product. This validation test sheet will help to find out which media model is being made. This validation sheet contains aspects of the Production Écrite Intermédiairesemester III teaching materials. This validation test sheet is filled out by expert lecturers, after seeing the teaching materials made. This validation test sheet is filled out by expert lecturers. In addition to providing corrections, this expert lecturer is also expected to provide input and suggestions for improving writing evaluation tools that have been made. So that the resulting product has better quality and feasibility than before. The following is the lecturer validation table:

Table 3. Production Écrite Intermédiaire Material Design Validation Test Sheet Table SIPDA Based

\begin{tabular}{|c|l|c|c|c|}
\hline $\begin{array}{c}\text { Aspect which } \\
\text { is Rated }\end{array}$ & \multicolumn{1}{|c|}{ Indicator } & \multicolumn{1}{|c|}{ Conformity } & Suggestion \\
\cline { 2 - 4 } Theory & $\begin{array}{l}\text { a. SIPDA used is in accordance with } \\
\text { the learning material. } \\
\text { b. The SPDA used is in accordance } \\
\text { with the learning objectives. }\end{array}$ & $\sqrt{ }$ & & \\
$\begin{array}{l}\text { c. SIPDA used is in accordance with } \\
\text { basic competencies }\end{array}$ & $\sqrt{ }$ & & \\
\hline \multirow{2}{*}{ Illustration } & $\begin{array}{l}\text { a. The SIPDA used can provide } \\
\text { illustrations that match the actual } \\
\text { teaching material }\end{array}$ & $\sqrt{ }$ & & \\
\hline
\end{tabular}




\begin{tabular}{|c|l|c|c|c|}
\hline & $\begin{array}{l}\text { b. SIPDA can make it easier for } \\
\text { learners to write text }\end{array}$ & $\sqrt{ }$ & & \\
\hline $\begin{array}{c}\text { Quality and } \\
\text { Media }\end{array}$ & $\begin{array}{l}\text { a. The presentation of material in } \\
\text { SIPDA attracts the attention of } \\
\text { learners } \\
\text { b. SIPDA material used } \\
\text { not easily broken }\end{array}$ & $\sqrt{ }$ & & \\
\hline Attractiveness & $\begin{array}{l}\text { a) The use of SIPDA can reduce the } \\
\text { dependence of learners on teachers } \\
\text { b. The use of SIPDA can minimize } \\
\text { misperceptions that occur in learners }\end{array}$ & $\sqrt{ }$ & $\sqrt{ }$ & \\
\hline
\end{tabular}

\subsection{Design Revision}

After knowing the weaknesses and some input from media experts, a revision of the teaching material design was carried out according to the suggestions of these experts, so as to produce a design that was ready to be implemented.

\section{Conclusion}

Based on the results of research and product development conducted by researchers, it can be concluded as follows:

1. Based on the analysis of needs through questionnaires for students and interviews with French lecturers, it can be seen that the SIPDA-based Production Écrite Intermédiaire teaching materials for third semester students are needed to improve their writing skills.

2. The result of this research and development is that the SIPDA-based Production Écrite Intermédiaire teaching material has a good impact in increasing the writing skills of the third semester students of the French Education Study Program.

Advice

Based on the above conclusions, the authors propose several suggestions, as follows:

1. For lecturers, this teaching material can be used as a Production Écrite Intermédiaire learning material for third semester students

2. For students, this teaching material can be used to practice writing French.

3. For researchers, this product is a new teaching material that requires further research to determine the effectiveness of using SIPDA to improve writing skills.

\section{References}

Borg, W., and Gall, M. (2003). Educational Researh; an Introduction 6th edition. Boston: Pearson.

Depdiknas, Panduan Pemgembangan Bahan Ajar, (2008), tersedia di http:// smpn1 pasarkemis. files.wordpress.com

Dick, W., Carey, L., \& Carey, J. O. (2001). The systematic design of instruction (5th ed.). New York: Addison-Wesley Educational Publisher Inc.

http:/ /ldikti3.kemdikbud.go.id/v6/2020/04/21/surat-edaran-direktur-jenderal-pendidikantinggi-kementerian-pendidikan-dan-kebudayaan-nomor-1-tahun-2020-tentangpencegahan-penyebaran-corona-virus-disiase-covid-19-di-perguruan-tinggikementerian/

Moore, J. L., Dickson-Deane, C., \& Galyen, K. 2011, E-Learning, online learning, and 
distance learning environments: Are they the same? Internet and Higher Education. https://doi.org/10.1016/j.iheduc.2010.10.001, pp. 14(2), 129-135.

Prasasti, T.I., Solin, M., Hadi, W. (2019). The Effectiveness of Learning Media Folklore Text of North Sumatera Based on Blended Learning by 10th Grade Students of Vocational High SchoolHarapan Mekar-1 Medan. Budapest International Research and Critics in Linguistics and Education (BirLE) Journal Vol 2 (4): 480-490.

Resien, Sitompul, H., and Situmorang, J. (2020). The Effect of Blended Learning Strategy and Creative Thinking of Students on the Results of Learning Information and Communication Technology by Controlling Prior Knowledge. Budapest International Research and Critics in Linguistics and Education (BirLE) Journal Vol 3 (2): 879-893. Syakur, A., et al. (2020). Developing English for Specific Purposes (ESP) Textbook for Pharmacy Students Using On-Line Teachingin Higher Education. Britain International of Linguistics, Arts and Education (BIoLAE) Journal Vol. 2 (1): 467-474.

Syakur, A., Sugirin, and Widiarni. (2020). The Effectiveness of English Learning Media through Google Classroom in Higher Education. Britain International of Linguistics, Arts and Education (BIoLAE) Journal Vol. 2 (1): 475-483.

Tarigan, Henry Guntur.2013. Menulis :Sebagai Suatu Keterampilan Berbahasa. Bandung Angkasa

Tim Puslitjaknov. (2008). Metode Penelitian Pengembangan. Jakarta: Departemen Pendidikan Nasional.

Unité des Politiques linguistiques, Cadre européen commun de référence. Strasbourg www.coe.int/lang-CECR

Wei, L. \& Zhang, M. (2008). "The impact of Internet knowledge on college students' intention to continue to use the Internet" Information Research, 13(3) paper 348. [Available at http://InformationR.net/ir/13-3/paper348.html from 13 August, 2008]. 